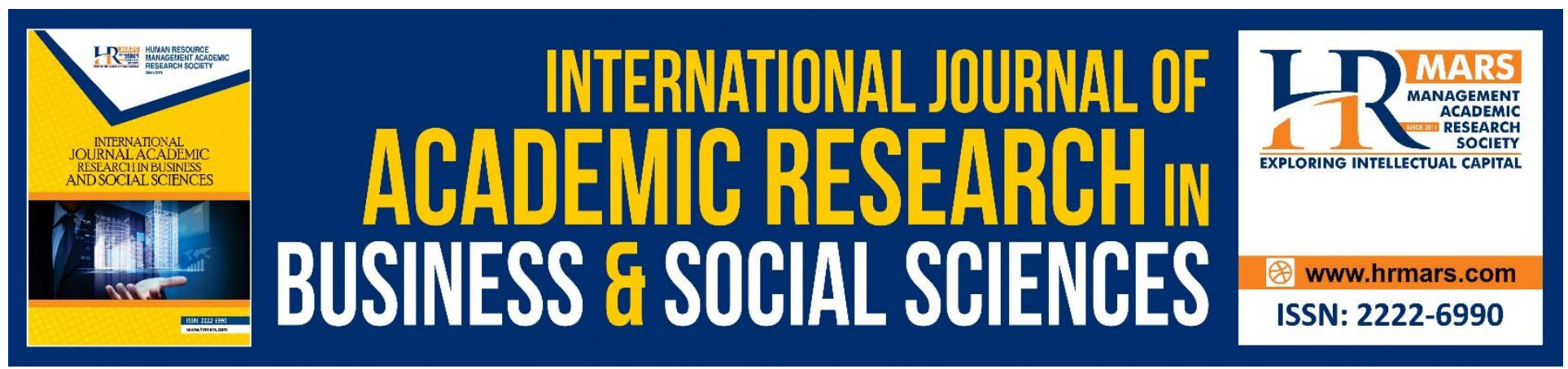

\title{
One Belt One Road: The Pursuit of Revolutionary Venture
}

\section{Mehrunnisa Khan}

To Link this Article: http://dx.doi.org/10.6007/IJARBSS/v8-i10/4765

DOI: $10.6007 /$ IJARBSS/v8-i10/4765

Received: 13 Sept 2018, Revised: 19 Oct 2018, Accepted: 26 Oct 2018

Published Online: 30 October 2018

In-Text Citation: (Khan, 2018)

To Cite this Article: Khan, M. (2018). One Belt One Road: The Pursuit of Revolutionary Venture. International Journal of Academic Research in Business and Social Sciences, 8(10), 578-594.

Copyright: (c) 2018 The Author(s)

Published by Human Resource Management Academic Research Society (www.hrmars.com)

This article is published under the Creative Commons Attribution (CC BY 4.0) license. Anyone may reproduce, distribute, translate and create derivative works of this article (for both commercial and non-commercial purposes), subject to full attribution to the original publication and authors. The full terms of this license may be seen at: http://creativecommons.org/licences/by/4.0/legalcode

Vol. 8, No. 10, 2018, Pg. 578 - 594

Full Terms \& Conditions of access and use can be found at http://hrmars.com/index.php/pages/detail/publication-ethics 


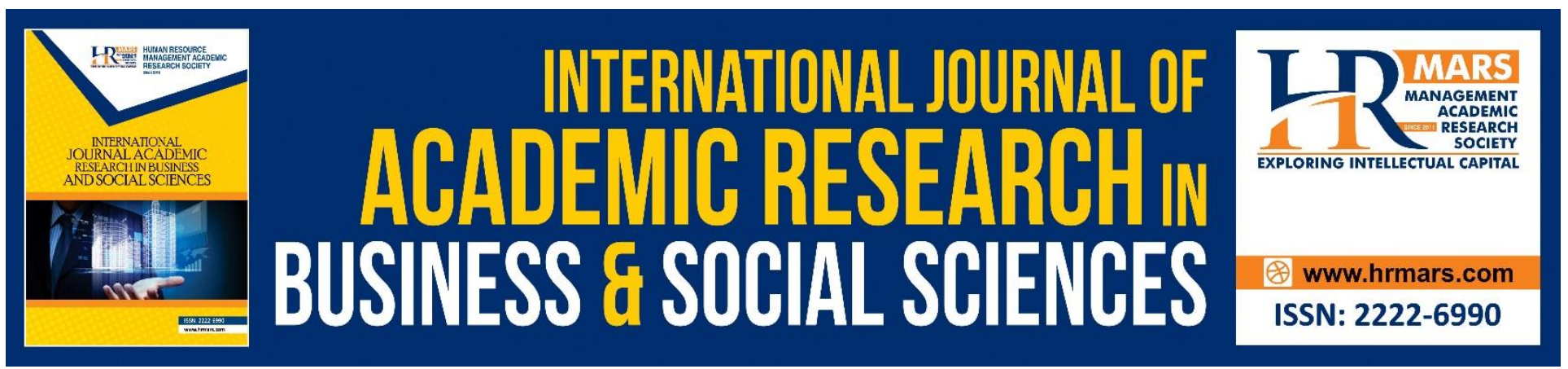

\title{
One Belt One Road: The Pursuit of Revolutionary Venture
}

\author{
Mehrunnisa Khan \\ College of Economics and Management, Nanjing University of Aeronautics and Astronautics, 29 \\ Jiangsu Avenue, Nanjing, China \\ Email: mehrkhan271@Yahoo.com
}

\begin{abstract}
This paper will analyse the OBOR initiative, Emphasizing its strengths and implementation challenges, scope and possibilities, contextualizes. The latter result from domestic constraints, tensions in China's neighbourhood, and great power rivalries. This initiative, One Belt and One Road (OBOR), comprises more than physical connections. It aims to create the world's largest platform for economic cooperation, including policy coordination, trade and financing collaboration, and social and cultural cooperation.
\end{abstract}

Keywords: OBOR, OBOR vision, Reliance on Geo, Objectives and potential, Attributes of OBOR.

\section{Introduction}

The Chinese Government has embarked on a new strategy, known as "One Belt, One Road" or OBOR. The concentrations for this project is to concentrate on the maritime part of this development policy (Thatcher et al., 2016), which entails heavy infrastructure investments in ports and railroads, but also property developments like satellite cities or condominiums, offered for sale mainly to Chinese citizens. There will be obvious commercial benefits to economies along the Southern Silk Road, but also geo-political effects like increasing political dependency due to Chinese capital investments and acquisition of property rights in ports and condominiums. One belt one road is one of the most ambitious foreign and economic policies. It aims to strengthen Beijing's economic leadership through a vast program of infrastructure building throughout China's neighbouring regions. One of the overriding objectives of OBOR is to address China's deepening regional disparity as the country's economy modernizes. The initiative will have a heavy domestic focus (Y. Zhang, 2015).

The Chinese government also wants to use OBOR as a platform to address the country's chronic excess capacity. In the midst of these developments China's leadership is putting massive initiatives and efforts for this on going global strategy, most notably these initiatives are shaped more and more by the project 'One Belt One Road' (Miu, Tjen-San, \& Leung, 2017). This project is gaining a wider recognition and momentum not even only within China, even outside the country. China's Belt and Road Initiative (BRI) is a multifaceted economic, diplomatic and geopolitical undertaking that has 
morphed through various iterations, from the "New Silk Road" to "One Belt One Road". At the end of 2013 Chinese President Xi Jinping announced one of China's most ambitious foreign policy and economic initiatives. He called for the building of a Silk Road Economic Belt and a 21st Century Maritime Silk Road, collectively referred to as One Belt, One Road (OBOR) but which has also come to be known as the Belt and Road Initiative. Xi's vision is an ambitious program of infrastructure building to connect China's less-developed border regions with neighbouring countries. OBOR is arguably one of the largest development plans in modern history. (Kuo, 2017) and (Bochra, 2015).

Along the Maritime Silk Road several major projects stand out. OBOR initiative permits new infrastructure and economic aid to be provided to needy economies. The term derives from the overland 'Silk Road Economic Belt' and the '21st-Century Maritime Silk Road', concepts introduced by PRC President Xi Jinping in 2013. These are the two major axes along which China proposes to economically link Europe to China through countries across Eurasia and the Indian Ocean. The OBOR initiative also links to Africa and Oceania (Overholt, 2015). The initiative envisages the building of six major economic cooperation corridors and several key maritime pivot points across Eurasia. The objectives includes,

China is leading the effort to create the world's largest economic platform, establishing a modern equivalent, creating a network of railways, roads, pipelines, and utility grids that would link China and Central Asia, West Asia, and parts of South Asia. This initiative, One Belt and One Road (OBOR), comprises more than physical connections. It aims to create the world's largest platform for economic cooperation, including policy coordination, trade and financing collaboration, and social and cultural cooperation. Through open discussion, OBOR can create benefits for everyone (Rowell, 2017). The State Council authorized an OBOR action plan in 2015 with two main components. The Silk Road Economic Belt and the 21st Century Maritime Silk Road (exhibit) (Clarke, 2016).

The Silk Road Economic Belt is envisioned as three routes connecting China to Europe (via Central Asia), the Persian Gulf, the Mediterranean (through West Asia), and the Indian Ocean (via South Asia). The 21st Century Maritime Silk Road is planned to create connections among regional waterways. More than 60 countries, with a combined GDP of $\$ 21$ trillion, have expressed interest in participating in the OBOR action plan (Römer, 2018). 


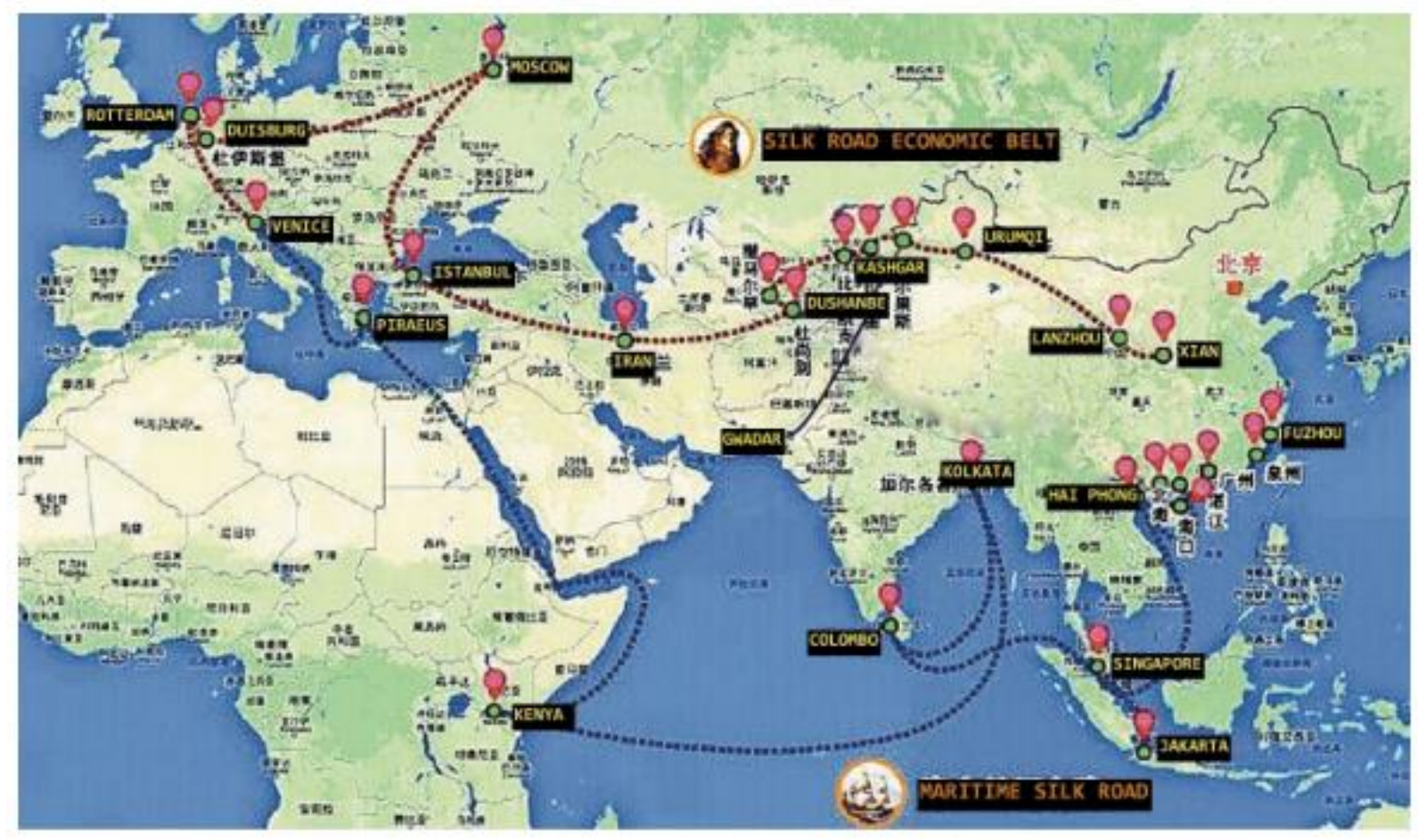

China seeks to take the interests of all parties into account so as to generate mutual benefits, including environmental management and closer cultural exchanges.

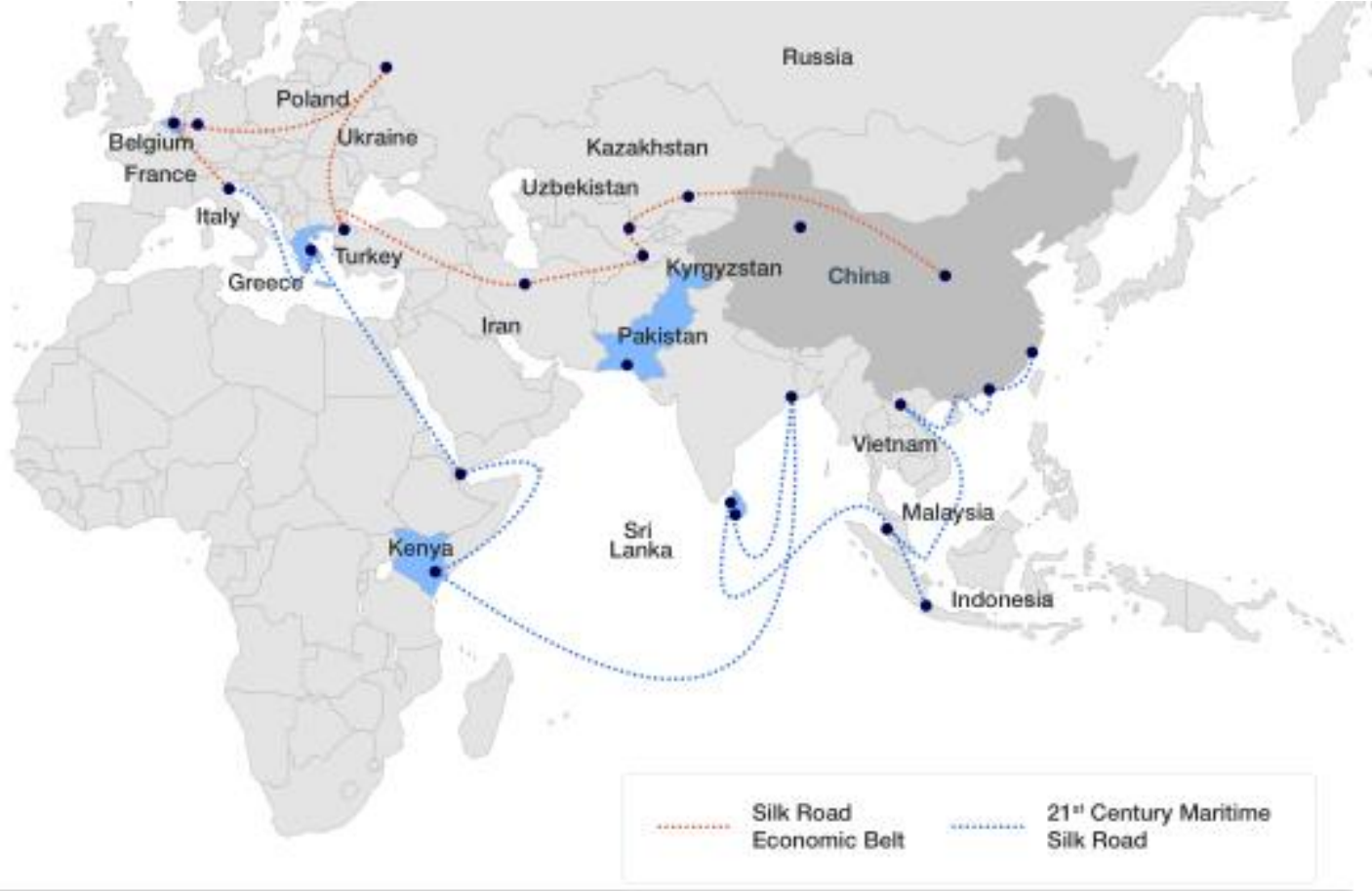

\section{AIM OF THE INITIATIVE}

The aim of Silk road economic belt is to build a "Eurasian land bridge" a logistics chain from China's east coast all the way to Western Europe, to develop the economic corridors connecting China with 
Mongolia and Russia, central Asia and South-East Asia (Du \& Zhang, 2018). The 21st-Century Maritime Silk Road a sea route rather than a road runs west from China's east coast to Europe through the South China Sea and the Indian Ocean, and east into the South Pacific. The aim of the sea route is to build efficient transport routes between major ports in various countries, including the development of an economic corridor through the Indian Ocean, better connecting China with South Asia, the Middle East, Africa and the Mediterranean. The OBOR initiative is being managed by a small group under the chairmanship of Vice-Premier Zhang Gaoli (LIM, 2016). In the Chinese government, the National Development and Reform Commission (NDRC), Ministry of Foreign Affairs and Ministry of Commerce have been tasked to deliver OBOR, with the NDRC playing a coordinating role. The official blueprint is for a circular route "connecting the vibrant East Asia economic circle at one end and the developed European economic circle at the other, and encompassing countries with huge potential for economic development". Formally, OBOR emphasises five key areas of cooperation: Coordinating development policies, forging infrastructure and facilities networks, strengthening investment and trade relations, enhancing financial cooperation and deepening social and cultural exchanges (The Hindu, 2015).

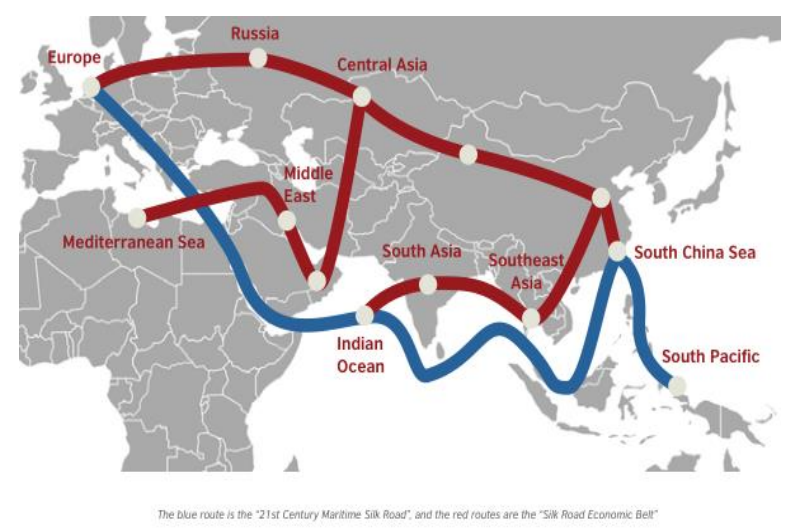

It has been described by the Chinese government as the third round of China's opening up after the development of Special Economic Zones and China's accession to the World Trade Organisation. President $\mathrm{Xi}$ Jinping has said that OBOR "should be jointly built through consultation to meet the interests of all, and efforts should be made to integrate the development strategies of the countries along the routes (C. Zhang, 2016). It is not closed but open and inclusive; it is not a solo by China but a chorus of all countries along the routes." Prosperity for underdeveloped parts of China, particularly in the west of the country. Increased connectivity and economic development along both routes through the movement of goods, services, information and people and the exchange of culture. Greater integration between China and its neighbours. Energy security through diversification of import sources. An outlet for domestic over capacity and overseas investment: China has overcapacity in several sectors, owing to the economic drive and building boom of recent decades. OBOR is seen as a viable outlet for excess production capacity (Mohsin, Zhou, Iqbal, \& Shah, 2018) and (Mohsin, Rasheed, \& Saidur, 2018). China has also accumulated a large amount of foreign exchange reserves and capital. OBOR presents channels for outward investment and the diversification of foreign exchange reserves. New markets for Chinese products and services: Diversifying export markets, especially in developing 
INTERNATIONAL JOURNAL OF ACADEMIC RESEARCH IN BUSINESS AND SOCIAL SCIENCES Vol. 8, No. 10, Oct. 2018, E-ISSN: 2222-6990 @ 2018 HRMARS

countries, will extend the lifecycle of Chinese products and will lay the ground domestically for the upgrading of traditional industries and the development of emerging industries.

\section{KEY ATTRIBUTES OF OBOR}

Most foreign analysts have hailed China's "One Belt, One Road" initiative as a "comprehensive strategy" or a "geopolitical and Diplomatic offensive." Meanwhile, Chinese officials consider it "an ambitious economic vision of the opening-up and cooperation". A systematic project governed by the Silk Road Spirit that seeks to build a community of shared interests, destiny and responsibility [National Development and Reform Commission (NDRC)2015].

However, the OBOR initiative is the most ambitious effort by China since the new leadership was elected at the $18^{\text {th }}$ Congress of the Communist Party of China in November2012. In October 2012, Professor Wang Jisi was the first Chinese scholar to speak about the need for China to revitalize three Silk roads, to Southeast Asia, to South Asia and to Central Asia. One year later, China's “One Belt, One Road "initiative came to prominence. President Xi Jinping, in a September 2013 speech at Kazakhstan's Nazarbayev University, called for the reviving of the ancient "Silk Road" by establishing the "Silk Road Economic Belt".Finally,on28March 2015, the National Development and Reform Commission, the Ministry of Foreign Affairs, and the Ministry of Commerce published the first document, titled "Vision andActionsonJointlyBuildingSilkRoadEconomicBeltand21stCenturyMaritimeSilkRoad".

Britain used to be called a nation of shopkeepers. China can be called a nation of contractors. Having built its way up to become a \$10-trillion economy, China is saddled with over-construction at home and is looking for new construction opportunities worldwide. The One-Belt-One-Road (Obor) initiative is partly driven by the need to sustain investment, even as domestic consumption and world trade are unable to sustain growth. This much is obvious. But this is not the full story. China's longdistance construction activity, both across China itself (from the east coast to Xinjiang and Tibet) and across Eurasia, has been driven as much by these economic calculations as it has been by geopolitical ones. Geopolitical analysts have long argued that China's rise has so far been unique in that, unlike most other 'Great Powers', it has become one without firing a single shot. China's has so far risen more as a 'geo-economic' power, using its economic muscle to browbeat difficult neighbours and economic partners.

As a geo-economic power, China has used its economic muscle to achieve geopolitical aims. This is not news. Over the last two decades, China has locked the West and Russia into a relationship of economic dependence by offering to their consumers low cost consumer goods. Russia President Vladimir Putin knows better than anyone that restive Russian citizens have been kept happy with access to low-cost goods from China.

\section{RELIANCE ON GEO}

China's economic initiatives on the foreign trade, investment and infrastructure construction fronts have underscored the wisdom of Nobel laureate economist and professor Thomas Schelling's famous words, "Aside from war and occasionally aside from migration, trade is the most important relationship that most countries have with each other. Broadly defined to include investment, 
shipping, tourism and the management of enterprises, trade is what most of international relations are about. For that reason, trade policy is national security policy."

The OBOR initiative is not only about economics. Without doubt it is about geo-economics the deployment of economic instruments in pursuit of geopolitical objectives.

\section{IMPACT ON CHINA'S ECONOMY}

There have been many queries over how the 'Belt and Road' initiative will achieve actualisation due to its immense cost requirement and subsequent infrastructure financing 'gap'. The issue is a result of China providing the majority of the funds. This is demonstrated by a 2015 case study where Beijing's Import and Export Bank of China lent $\$ 80$ billion USD to the initiative compared to the Asian Development Bank which lent $\$ 27$ billion USD. Given that the Asian Development Bank estimate the initiative will cost over $\$ 22.6$ trillion USD by 2030 it brings into question how China will be able to continue burdening this weight of carrying the initiative.

The answer lies in China's financing resources such as: The Silk Road Fund, the 10 major cooperation projects announced at the Forum on China-Africa Cooperation, the AlIB, The New Development Bank and loans from Chinese policy banks. In addition, the Belt and Road Initiative will eventually start paying for itself or at least providing significant returns; as of March 2017, Chinese companies have made over $\$ 50$ billion USD from investments related to the initiative and many projects have already been launched in countries connected through the initiative. Within the first eight months of 2016, China's trade with BRI countries exceeded $\$ 600$ billion USD. Estimates suggest that the initiative will make China's annual trade along the Belt and Road over \$2.5 trillion USD. Aside from monetary returns, the initiative provides an outlet for China's immense industrial capacity. It creates and protects jobs in the industrial field as well as helping to maintain economic growth. Furthermore, the connections to Russian and Iranian oil and gas will protect China's energy needs whilst pipelines on the coast of countries such as Myanmar and Pakistan enables more diverse maritime routes and thus a greater outlet for Chinese goods. Exports to BRI countries have grown faster than total exports since 2013 demonstrating the potential of the Belt and Road initiative for China's growing economy.

\section{The Potentials of One Belt One Road}

According to Asian Development Bank estimate in 2009, the 45 developing member countries (DMCs) in Asia will requires approximately USD 8 trillion infrastructure investment in the next decade to sustain its current grow momentum. 


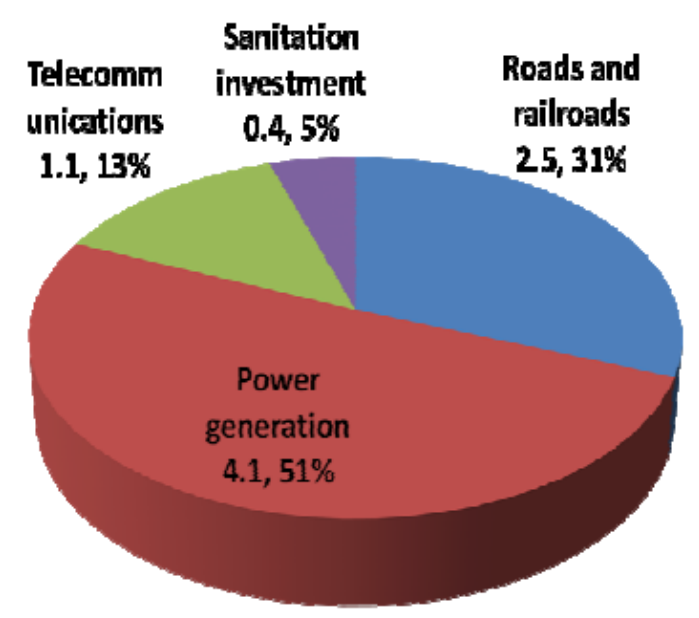

A new estimate in 2016, the 45 DMCs will need to invest USD 26 trillion over the 15-year from 2016 to 2030, or US\$ 1.7 trillion per year. Of the estimate, \$ 14.7 trillion will be for power, $\$ 8.4$ trillion for transportation, $\$ 2.3$ trillion for telecommunications, and $\$ 800$ billion for water and sanitation.

\section{POTENTIAL EXPANSION OF RENMINBI}

Firstly, it is worth noting that at this current moment the US dollar is still the most popular choice of currency for settlements along the Belt and Road. Whilst it is not a specific aim of The Belt and Road Initiative the initiative provides three possible routes through which Renminbi could be internationalized. (I) BRI could promote RMB settlement through the current account. Currently China is aiming for their trade with BRI countries to reach around \$2.5 trillion USD per year within the next 10 years. Given that China is promoting the use of RMB on the Belt and Road this would mean an immense amount of RMB exchanging hands internationally. In addition, greater export of goods and services along the Belt and Road will mean an increased demand for RMB trade settlement and currency mobility. For example, in 2015 Chinese companies signed 3,987 construction contracts in BRI countries this is $44.1 \%$ of the value of Chinese overseas construction projects. (II) The Initiative could improve RMB outflows through the capital account. Between January 2012 and September 2015, the number of China's Outward Direct Investments (ODI) settled in RMB increased from 0.2 billion RMB to 20.8 billion RMB. The Belt and Road Initiative means more markets.

For example; In 2015 China's Outward Direct Investments (ODI) involved 49 BRI countries with investments connected to BRI reaching USD $\$ 14.8$ billion (18.2\% higher than 2014). ODI's in BRI countries will increase with its development and thus RMB outflow will rise through the capital account as well as RMB trade settlements for BRI countries are more likely to utilize RMB to avoid transaction fees and exchange rate issues. (III) BRI could promote the international spread of RMB as a store of value. Already the demand for RMB in BRI countries is increasing and countries along the Belt and Road are becoming more open to using RMB as a reserve asset. The initiative will also encourage countries to use RMB in their foreign exchange reserves, South Korea, Malaysia and Cambodia have already made RMB one of their reserve currencies, a trend expected to be followed 
with the growth of the initiative. Another contributing factor to the spread of RMB, which will only be enhanced by BRI is the inclusion of RMB by the IMF in the Special Drawing Rights (SDR) Basket on the $1^{\text {st }}$ October 2016. Other currencies in the basket are USD, GBP, EUR, JPY, China is the first emerging economy to be included. Being in the SDR Basket massively boosts RMB credibility with international investors; the People's Bank of China ( $\mathrm{PBOC}$ ) predicts that following this move RMB in foreign central banks' official reserves could exceed 4\% soon. Furthermore, Standard Chartered Bank predicts that the total net purchases of China's bonds and stocks could reach RMB 5.5 trillion (\$791 billion USD) and RMB 6.2 trillion respectively by 2020. The inclusion of RMB encourages the Chinese government to continue banking and financial sector reforms as well as capital-account liberalization. If this reform and economic growth continues then RMB denominated assets will become increasingly regarded as 'safe assets' by global investors and sovereigns. As Euro zone bonds are not viewed as being as safe as they were pre-2008 downgrades have been issued to many European countries including Austria, the UK, the US and France resulting in the decline of their supply of global 'safe assets'. Banks need more low-risk assets to meet regulatory requirements. Since the debt issues of developed countries cannot easily be solved there is the prospect of emerging economies such as China to develop opportunities for banks that satisfy the need for risk-free or low-risk assets. IF RMB becomes seen as a safe and liquid asset the demand for RMB will increase. Standard Chartered Bank predicts proportion of RMB assets in global foreign exchange reserves will increase from $1 \%$ to $5 \%$ within 5 years. In addition, RMB is affected by the growth and international respect of Chinese bank AllB. Through the increased credibility and use of RMB BRI countries will be even more inclined to utilize RMB in trade.

Estimates from the Chinese Government suggest that by 2020 half of China's foreign trade will be settled in RMB. Peter Wong, Deputy Chairman and Chief Executive, The Hong Kong and Shanghai Banking Corporation Limited says, "As the commercial activities between China and countries along the BRI become more frequent, RMB will gain wider acceptance." Consequently, HSBC recommended that "companies who haven't already adopted RMB should consider doing so now if they plan on participating in BRI growth and expansion." BRI growth has many advantages for foreign investors as laid out previously under 'How the Belt and Road Initiative can affect Foreign Investors'.

\section{WORLD INSTITUTIONS AND THE BELT ROAD INITIATIVE}

\section{The United Nations (UN)}

In May 2017 at the 'Belt and Road Forum for International Cooperation', the Secretary General of the UN declared his support for the initiative. Quoting a famous Chinese saying he proclaimed that; "Building the road is the first step towards prosperity". This follows on from September 2016 where the United Nations Development Programme (UNDP) and the People's Republic of China (PRC) signed a 'Memorandum of Understanding' (MOU) on cooperation over the Belt and Road Initiative. This is a strategic cooperation designed to speed up and increase the likeliness of achieving both BRI and the 2030 'Agenda for Sustainable Development'. Following on from the MOU, an 'Action Plan' for the Belt and Road Initiative was signed by both parties in May 2017. Within the speech at the 2017 Forum, the Secretary General proclaimed that; "For countries yearning to become more integrated with the global economy, it (BRI) can promote access to markets." 


\section{The World Bank group}

The initiative has received both verbal and monetary support from the World Bank Group. In May 2017, the World Bank Group's president Jim Yong Kim announced that the World Bank Group were committed to paying $\$ 86.7$ billion USD towards development and connectivity projects in BRI countries. In the words of Jim Yong Kim; "The Belt and Road Initiative has potential to lower trade costs, increase competitiveness, improve infrastructure, and provide greater connectivity for Asia and its neighbouring regions".

\section{The International Monetary Fund (IMF)}

The IMF is increasingly recognising China as a force to be reckoned with on the global economic stage as is evident by its adding the Renminbi to the basket of 'special drawing rights' (SDR) in October 2016. Other currency in this basket include; US Dollar, Yen, Euro and Sterling. China is the first emerging-market currency to be included in the SDR basket. This action promotes the credibility of $\mathrm{RMB}$ and thus makes it more likely to be utilised by 'Belt and Road' countries.

\section{The European Union (EU)}

There is an agreed EU-China connectivity platform which involves cooperation on investment projects (predominantly on the Belt and Road). In June 2017, the 19th summit for the EU and PRC was held. This resulted in developments on the extent of their cooperation. Developments were focused on the field of transport connections between the two and cooperation on 'green' transport solutions. Further movements were also made regarding; "concrete projects based on agreed criteria including sustainability, transparency and a level-playing field." (In the words of the EU's official website). The European Investment Fund and the Silk Road Fund also signed an MOU committing €250 million from each fund towards private equity and venture capital funds. Key Port Cities includes, Kuantan (Malaysia), Kyaukpyu (Myanmar), Jakarta and Batam Island (Indonesia), Colombo and Hambantota (Sri Lanka), Gwadar (Pakistan), Djibouti (near red sea), Mombasa (Kenya) and Piraeus (Greece).

\section{The Corridors:}

\section{The New Eurasia Land Bridge:}

This corridor, as proposed by China, will take the form of an international railway line from China's Jiangsu province essentially in a horizontal line west to Rotterdam in Holland. According to plans it will be $11,800 \mathrm{~km}$ long and will serve over 30 countries. Along this corridor, China has already opened four freight train routes. These include a route from Chongqing to Duisberg (Germany), a direct route from Wuhan to Mēlník to Pardubice (Czech Republic), a route from Chengdu to Lodz (Poland) and one from Zhengzhou to Hamburg

(Germany). 


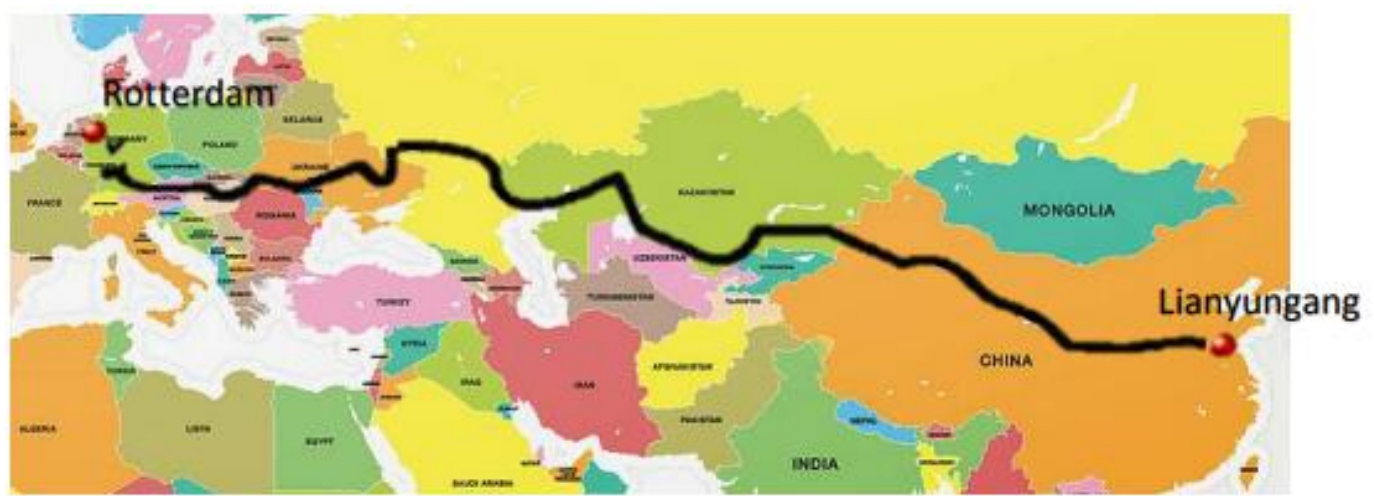

In addition, along these routes China has issued the policy "one declaration, one inspection, one cargo release" to improve efficiency and ease. Further construction projects of power transmission lines, highways and ports are progressing steadily.

\section{The China-Mongolia-Russia Economic Corridor:}

This includes the three countries mentioned and is focused on two main routes; one being: BeijingTianjin-Hebei region-Hohnot-Mongolia-Russia and the other being: Dailan-ShenyangChangchunHarbin and Manzhouli to Russia's city Chita.

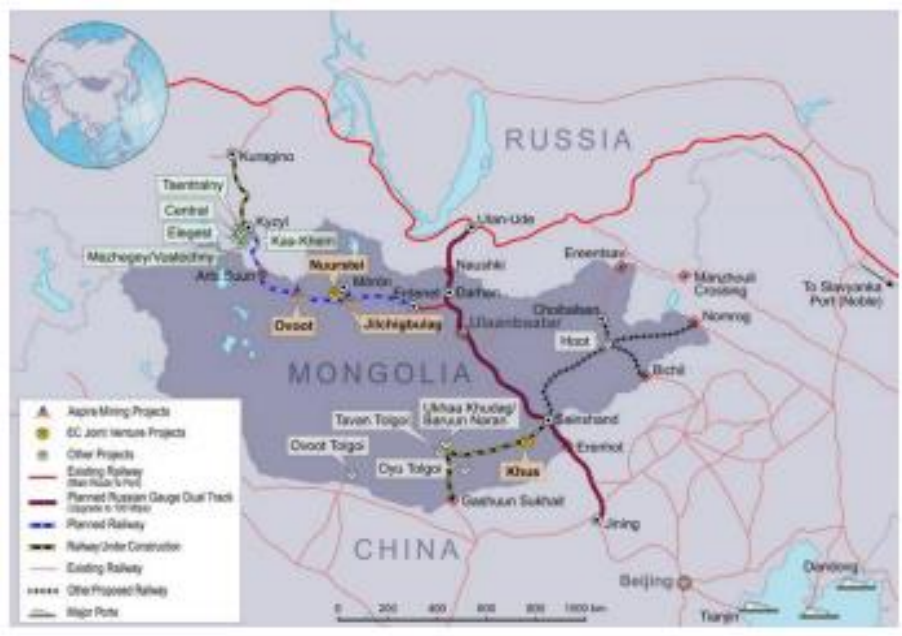

As far as the development of this corridor there were two major breakthroughs. First, in September 2014 the three Heads of State of the countries in question met at the Shanghai Co-operation Organisation (SCO) Dushanbe summit. Here they agreed on a tripartite cooperation based on bilateral ties. In addition, they agreed to renovate Russia's Eurasian Land Bridge and potentially develop Mongolia's Steppe Road. The intention of their agreement was to strengthen railway and highway connectivity, advance customs clearance, transport facilitation and promote cross-national cooperation. The second breakthrough was in July 2015 at a second summit held in Ufa in which the 'mid-term road map for Development of trilateral Co-operation between China, Russia and Mongolia' was formally adopted. In June 2016, the three countries created a development plan to follow through with. Further agreements were signed in the Belt and Road initiative forum held in May 2017. In August 2016, a ceremonial delegation of trucks from the three countries was sent out to test the proposed corridor. 
INTERNATIONAL JOURNAL OF ACADEMIC RESEARCH IN BUSINESS AND SOCIAL SCIENCES

Vol. 8, No. 10, Oct. 2018, E-ISSN: 2222-6990 @ 2018 HRMARS

\section{China-Central Asia-West Asia Economic Corridor:}

This corridor is from Xinjiang to Alashankou to the railways of Central and West Asia to the Mediterranean Coast and finally the Arabian Peninsula. The corridor mainly covers; Kazakhstan, Kyrgyzstan, Tajikistan, Uzbekistan, Turkmenistan in Central Asia and Iran and Turkey in West Asia (although in total including 17 countries in West Asia). This corridor generally follows the path of the Ancient Silk Road. The most significant movement in developing this corridor was in June 2015 at the 'Third China-Central Asia Co-operation Forum' held in Shandong. Here a joint declaration was signed by China and the 5 central Asian countries committing to 'jointly building the Silk Road Economic Belt'. In 2016, the AIIB approved a loan of \$27.5 million USD Dushanbe-Uzbekistan Border Road improvement project in Tajikistan. In 2017, the rehabilitation of Nurek hydropower plant in Tajikistan was announced.

\section{China-Indochina Peninsular Economic Corridor (CIPEC):}

This route is from the Pearl River Delta and goes west along the Nanchong-Guang'an Expressway and Nanning-Guangzhou high speed railway via Nanning and Pingxiang to Hanoi and Singapore. It links China with the Indochina peninsular and goes through Vietnam, Laos, Cambodia, Thailand, Myanmar and Malaysia. As far as advances go, in December 2014 during the 'Fifth Leaders Meeting on Greater Mekong Sub-regional' in Bangkok, Chinese Premier Li Keqiang proposed ways to deepen ties with the 5 countries in the Indochina Peninsular.

Nine cross-border motorways in the area of the Greater Mekong Subregion are currently under construction. In the South, China has funded and built various roads in several regions of Indonesia. The Kunming-Singapore High-speed Rail network is a project designed to connect China to Indochina through 3 high-speed railway routes; East, via Hanoi, Ho Chi Minh, Phnom Penh and Bangkok, Central (via Vientiane, Bangkok, Kuala Lumpur and Singapore) and West, (via Mandalay, Yangon and Bangkok). Most of this railway project within China is already complete and the railway is in operation in parts of Vietnam. Western segments are currently under construction whilst Malaysia and Singapore are jointly upgrading sections from Thailand to Singapore. Within this corridor there are many plans for Air route expansion and integration ASEAN and China have already made a deal to allow Chinese airplanes to use ASEAN gateway city airports. This is in addition to the ASEAN 'open skies policy', a policy which all ASEAN countries have a ratified agreement except for Indonesia, Laos and the Philippines who are still in the process of fully enacting it. Currently there are developments in the linking of Southeast Asian ports to major Chinese cities. The ASEAN region has a lot of potential for untapped coal, oil and gas which are likely to be utilised within next 10 years. China already has many projects in this area underway for example, in Laos, China's Three Gorges Corporation has completed two hydropower projects.

\section{Opportunities and Challenges}

This corridor is made of ASEAN members most of whom already have a series of exceptionally well developed economic agreements, this will make trade easier. With the development of these countries there are many opportunities to develop the banking, finance and other professional services sector particularly since Cambodia, Laos and Myanmar are revising regulations to encourage 
growth in this sector. Furthermore, regional institutions like the Asian Development Bank (ADB) are encouraging sustainable and efficient agriculture within this region. However, China's ties with Indochina are tense which may put a halt on the initiative in this corridor. For example, various CIPEC projects have been delayed due to disagreements over money.

\section{China-Pakistan Economic Corridor}

This route is $3000 \mathrm{~km}$ long and starts in Kashgar ending in Gwadar, connecting the Silk Road Economic Belt in the North and the 21st Century Maritime Silk Road in the South. In April 2015 both countries signed a joint declaration which stated that the two countries would be proactive in their joint projects that are designed to further connect the two countries. China has already invested $\$ 62$ billion into the China-Pakistan economic corridor. Along this corridor there is the plan to make Gwadar a special economic zone: a 'new Dubai'. The Gwadar port is central to the corridor with China investing f1.3 billion in order to develop it into a deep-sea port which will be managed by China under a 43 year lease granted to Chinese Overseas Ports.

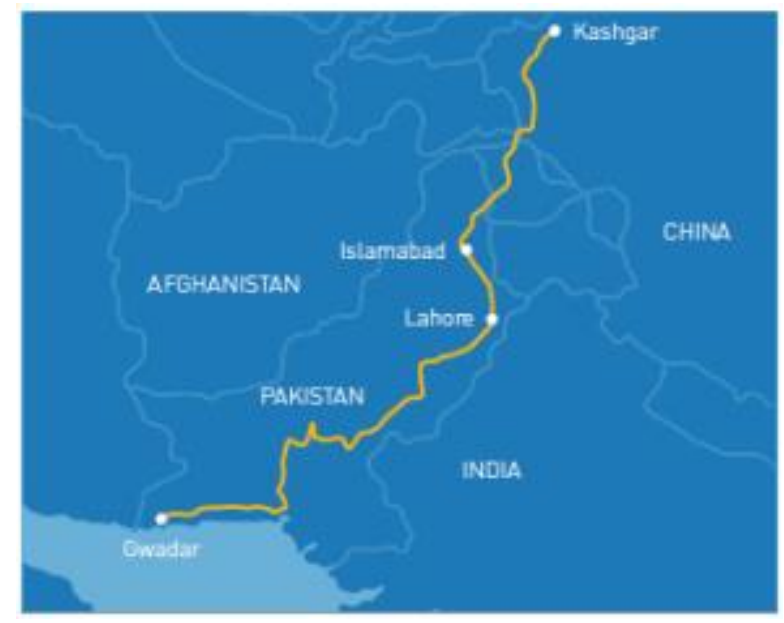

With the hopes to make Gwadar into a 'new Dubai' there are plans to turn it into an oil city with petroleum refining zone as well as hubs for mining and minerals, agriculture, food processing, technology and advanced manufacturing. There are also plans for a new Gwadar International Airport and Chinese investment in energy and water infrastructure. Furthermore, China is hoping to develop tertiary sectors and residential projects in Gwadar e.g education, business services, retail and leisure elements. In addition, there are plans for a Gwadar-Kashgar pipeline and transport network. This will be a network of railways, road, telecommunications and energy supply. The oil pipeline will cover $17 \%$ of China's oil imports. It will be financed by China and built by Pakistani Frontier Works Organisation however, it will be technically difficult due to mountainous terrain.

Over half of the investments in this corridor will be focused on energy projects in order to combat Pakistan's energy shortage. These projects are expected to double Pakistan's electricity capacity. China has already invested much in coal fired, nuclear energy and green energy. Current developments include what is set to be the world's largest solar plant in Bahawalpur, a hydropower plant in Karot, a wind power plant in Jhimpir, two nuclear power stations near Karachi and a major 
coal-fired power plant is being planned in Qasim which is aiming at providing around 20\% of Pakistan's energy shortfall.

\section{Opportunities and Challenges}

The Gwadar port will require technical and logistical investment, technical assistance in ports and petroleum refining zones as well as general shipping and maritime services. For the nuclear, solar and wind power plants there is a demand for companies specialised in design, construction and efficient maintenance. The Gwadar-Kashgar pipeline needs technical expertise to overcome mountainous technical issue However, there have been previous deals along this corridor that have fallen through previously due to issues of corruption and lack of transparency. Furthermore, there are issues between the Pakistani central government and local governments not cooperating as well as concerns over security across the country.

\section{Bangladesh-China-India-Myanmar Economic Corridor}

This route includes the four countries mentioned with an emphasis on India. This corridor will cover $9 \%$ of the planets land mass and 440 million people. The main part of the corridor is a $2,800-\mathrm{km}$ route running as follows; Kolkata-Dhaka-Mandalay-Kunming. It will take the form of a series of railways, motorways, airways, waterways and telecom networks.

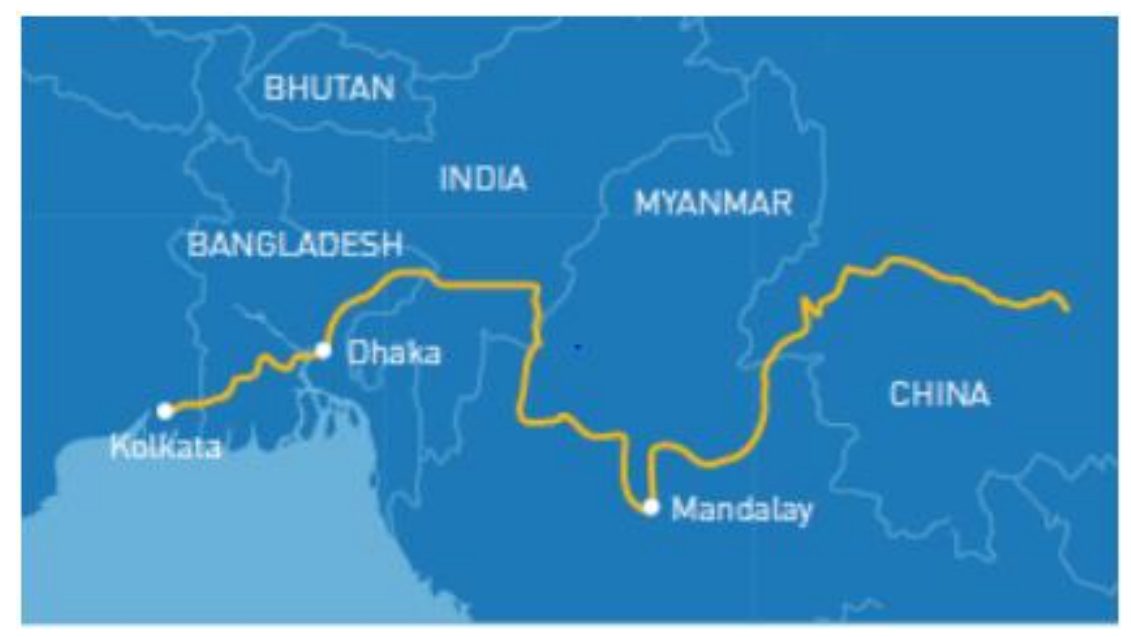

In May 2013 China and India jointly proposed building this corridor together. In December 2013, the 'Working Group' of the corridor met in Kunming. Here official representatives of the four countries embarked on in-depth discussions. Following this the countries signed meeting minutes agreeing to the 'Bangladesh-China-India-Myanmar Economic Corridor Joint Study Programme' establishing roots for cooperation between the four countries.

\section{Bangladesh}

Bangladesh's 'Vision 2021' proposed by the Bangladeshi government is focused on creating links with its neighbours as a main priority. In Bangladesh, the main area of investment will be energy, telecommunications and agriculture. Already, large transport infrastructure projects are being carried out such as Chinese companies building a $£ 3.6$ billion railway from Dhaka to Jessore. Energy 
INTERNATIONAL JOURNAL OF ACADEMIC RESEARCH IN BUSINESS AND SOCIAL SCIENCES

Vol. 8, No. 10, Oct. 2018, E-ISSN: 2222-6990 @ 2018 HRMARS

infrastructure is also being developed, Bangladesh-China power company Itd are focused on building $£ 1.3$ billion coal-fired power plant in South Dhaka furthermore, the AllB have approved a $£ 133$ million loan for Bangladesh to expand electricity into rural areas.

$\underline{\text { India }}$

In 2015 China and India signed a $£ 17.7$ billion trade agreement with a focus on renewable energy, steel, transport infrastructure and real estate sectors e.g Chinese company Wanda Group are building an $£ 8$ billion industrial park in Haryana near Delhi.

\section{Myanmar}

Here there is a large twin gas and oil pipeline project from the port of Kyaukpyu to Guanxi and Yunnan. The gas pipeline is already in use and the oil pipeline opened in April 2017. China is highly invested in Kyaukpyu and have developed the 'Kyaukpyu Special Economic Zone' including a deepsea port at Kyaukpyu which is under development led by Chinese CITI Group Corporation. China led power and energy projects across Myanmar are already in action as is demonstrated by the $£ 2.4$ billion refinery in the South East which was granted approval in 2016.

\section{Opportunities and Challenges}

Within this corridor there are issues over environmental concerns and security issues in all countries within the corridor. In addition, it is the least developed corridor. That being said, there are long-term opportunities in Shipping and Maritime services as well as technical and logistical support. By building greater connectivity and developing nations, once completed, the initiative will make it easier for large multinationals and start-ups alike to reach new large consumer markets. It has been estimated that the growing middle class in Asia could number 4 billion by 2021 and following on from this (according to HSBC) 66\% of the world's population could be living in Asia by 2030 . This will mean a continuously growing buyers' market in Asia demanding luxury goods and services. It is worth noting that the initiative will reportedly be open to all nations and not limited by geography. Thus, the benefits of easy access to a growing market will be accessible to all investors regardless of their geographic background. Consequently, through the initiative this immense market will be accessible for all.

The Belt and Road Initiative could be a good investment for private investors due to President Trump's move to back out of the Trans-Pacific Partnership (TPP). The action means the Belt and Road Initiative is likely to gain more popularity and momentum as it is aimed at providing a vast network for international trade similar to the TPP. As the US are starting to become more introverted there is gap being left on the world's economic stage which will likely be filled by China. This view is supported by Louis Kuijs, head of Asia Economics at Oxford Economics in Hong Kong. By investing in the initiative's developing countries, investors are investing in creating more buying power and establishing ef-ficient routes to fully utilise these new markets.

The Chinese government are encouraging a mixture of foreign investment and domestic investment in Belt and Road projects. Various banks and funds such as The New Development or 'BRICS' Bank and The Asian Infrastructure Investment Bank (AIIB) are providing loans for such projects. In 2016 AllB committed $\$ 1.73$ billion USD to nine development projects along the Belt and Road. According to the Articles of Agreement of the Bank they will "provide or facilitate financing to any member, or 
INTERNATIONAL JOURNAL OF ACADEMIC RESEARCH IN BUSINESS AND SOCIAL SCIENCES Vol. 8, No. 10, Oct. 2018, E-ISSN: 2222-6990 @ 2018 HRMARS

any agency, instrumentality or political subdivision thereof, or any entity or enterprise operating in the territory of a member, as well as to international or regional agencies or entities concerned with economic development of the Asia region". AlIB has three main requirements for financing projects: sustainable in operation, environmentally friendly and widely accepted by public society. According to a China-Britain Business Council (CBBC) report, "immediate key sectors are infrastructure, maritime and logistics, banking and financial services, professional services and energy. Further opportunities also exist in the agriculture, fishing, food processing, light equipment manufacturing, education, tourism and consumer sectors".

\section{Conclusion}

The Confucians discourse describes China as peaceful, unique, defensive and non-expansionist country. On the other hand, China is presented as a great power, with a historical role on the international arena, given by its size, culture and economy. The Belt is a long-term Chinese connectivity vision, It therefore allows a great deal of flexibility and could possibly become a leading new model of cooperation and global governance. OBOR is President Xi's most ambitious foreign and economic policy initiative. The most achievable of OBOR's goals will be its contribution to upgrading China's manufacturing capabilities. In the longer term, there will be macro impacts for international firms. One of the primary objectives of the Belt and Road initiative is to facilitate smoother trade flow within the connected regions, essentially building infrastructure to drive shorter lead times and reduced transportation costs. Improved linkage via railways and maritime connectivity is expected to further reduce the transit time between Europe and China.

Joseph Matthews, director of the Association of Southeast Asian Nations Education Center. Without peace, economic development of any region or country is impossible. The Belt and Road Initiative is the beginning of a new era of development in the region, and in the future this road will be known as the Peace Road. The land route will also emerge as an interesting option for the movement of goods, being significantly more cost effective than air-freight, and a possible alternative to sea transportation. This will greatly benefit organisations that rely on raw materials from the region as well as international players who are seeking to further penetrate large consumer markets like China and South Asia with their finished products. Helga Zepp-LaRouche, president of the Schiller Institute think tank in Germany. The Belt and Road Initiative will continue to grow and become a true world land bridge. It not only brings economic prosperity to all participating countries, but also serves as a true basis for a peace order for the 21st century.

\section{References}

Bochra, M. (2015). One Belt, One Road. Baltic Transport Journal /, 60-62. https://doi.org/http://dx.doi.org/10.1108/17506200710779521

Clarke, M. (2016). "One Belt, One Road" and China's emerging Afghanistan dilemma. Australian Journal of International Affairs, 70(5), 563-579. https://doi.org/10.1080/10357718.2016.1183585

Du, J., \& Zhang, Y. (2018). Does One Belt One Road initiative promote Chinese overseas direct investment? China Economic Review , 47, 189-205. https://doi.org/10.1016/j.chieco.2017.05.010 
INTERNATIONAL JOURNAL OF ACADEMIC RESEARCH IN BUSINESS AND SOCIAL SCIENCES

Vol. 8, No. 10, Oct. 2018, E-ISSN: 2222-6990 @ 2018 HRMARS

Kuo, L. (2017). China's new Silk Road, One Belt One Road project has one major pitfall for African countries. Retrieved from https://qz.com/983581/chinas-new-silk-road-one-belt-one-roadproject-has-one-major-pitfall-for-african-countries/

LIM, W. X. (2016). China's One Belt One Road Initiative: A Literature Review. In China's One Belt One Road Initiative (pp. 113-131). https://doi.org/10.1142/9781783269303_0008

Miu, R., Tjen-San, C., \& Leung, C. (2017). One Belt One Road infrastructure Sector. Asian Insights SparX. DBS Group Research, Equity.

Mohsin, M., Rasheed, A. K., \& Saidur, R. (2018). Economic viability and production capacity of wind generated renewable hydrogen. International Journal of Hydrogen Energy. https://doi.org/10.1016/j.ijhydene.2017.12.113

Mohsin, M., Zhou, P., Iqbal, N., \& Shah, S. A. A. (2018). Assessing oil supply security of South Asia. Energy, 155, 438-447. https://doi.org/10.1016/j.energy.2018.04.116

Overholt, W. H. (2015). One Belt, One Road, One Pivot. Global Asia, 10(3), 1-8. Retrieved from http://usa.chinadaily.com.cn/opinion/2014-09/03/content_18540267_2.htm

Römer, M. (2018). One Belt, One Road, One Korea? The Diplomat. Retrieved from http://thediplomat.com/2018/02/one-belt-one-road-one-korea

Rowell, C. (2017). CHINA'S ONE BELT ONE ROAD INITIATIVE: TOWARDS MUTUAL PEACE \& DEVELOPMENT. Business Chief Asia, 54(Jun), 2017-2018. Retrieved from http://asia.businesschief.com/leadership/458/Chinas-One-Belt-One-Road-OBOR-initiative:-anupdate

Thatcher, A., Waterson, P., Thatcher, A., Hancock, P., Davis, M. C., Zink, K. J., ... Waterson, P. (2016). This Changes Everything. Proceedings of the Human Factors and Ergonomics Society Annual Meeting, 60(1), 871-875. https://doi.org/10.1177/1541931213601199

The Hindu. (2015). China's “One belt One Road" initiative: Strategic significance. Civil Service Strategist. Retrieved from http://www.civilservicesstrategist.com/china-s-one-belt-one-roadinitiative-strategic-significance.html

Zhang, C. (2016). The "One Belt One Road" Initiative and China's Economic Transformations. ProQuest Dissertations and Theses. https://doi.org/ProQuest 10193762

Zhang, Y. (2015). One Belt, One Road : A Chinese View. Global Asia, 10(3), 8-12. 